\title{
Palynodiversity patterns and paleoclimatic changes in the late Paleozoic in Brazil and Uruguay
}

\author{
Á. Beri ${ }^{(1)}$, X. Martínez-Blanco(1), L. Tejera(1), A. Piñeyro(1) y P. A. Souza ${ }^{(2)}$ \\ (1) Laboratorio de Palinología, Instituto de Ciencias Geológicas, Facultad de Ciencias, Iguá 4225, Montevideo 11400, Uruguay. \\ beri@fcien.edu.uy; xmartinez@fcien.edu.uy; lete@fcien.edu.uy; apineyro@fcien.edu.uy \\ (2) Departamento de Paleontologia e Estratigrafia, Instituto de Geociências, Universidade Federal do Rio Grande do Sul, \\ Av. Bento Gonçalves, 9500, CP 91540-000, Porto Alegre, RS, Brazil. \\ paulo.alves.souza@ufrgs.br
}

\begin{abstract}
We have analysed the diversity of the late Paleozoic palynoflora of the Paraná (Brazil and Uruguay), Parnaíba and Amazon (Brazil) basins using already published data. In order to do this the total diversity and diversity with range-through approach curves were built up, as well as Foote's appearance and disappearance rates at the generic level. These parameters were also obtained separately for each group of sporomorphs. An important increase in diversity in the Asselian and Sakmarian and a posterior decrease until the Lopingian were observed. The values of the appearance rates were higher than those of disappearance and they peaked in the Asselian, while the highest disappearances took place in the Capitanian and, to a lesser extent, in the Sakmarian. On the other hand, spores and pollen grains show some differences in the general diversity trend. However, there are differences in the patterns of appearance and disappearance. Despite possible biases, mainly related to the collecting effort, the diversity curves and appearance and disappearance rates obtained are congruent with the climatic phases proposed for this region in these periods. The increase in the number of palynomorph genera is associated to the early Permian climatic amelioration whilst a decrease in diversity is related to the beginning of an arid phase.
\end{abstract}

Keywords: Brazil, diversity, Paleozoic, Palynology, Uruguay.

\section{La diversidad palinológica y los cambios climáticos en el Paleozoico Superior en Brasil y Uruguay}

\begin{abstract}
RESUMEN
Se analizó la diversidad de la palinoflora correspondiente a estratos del Paleozoico superior de las cuencas de Paraná (Brasil y Uruguay), Parnaíba y Amazonas (Brasil), utilizando datos previamente publicados. Se elaboraron curvas de diversidad total y diversidad calculadas mediante el método range-through y se calcularon los índices de aparición y desaparición de los diferentes géneros utilizando como herramienta el índice de Foote. También se analizaron esos parámetros en diferentes grupos de esporomorfos por separado. Se observó un aumento importante de la diversidad en el Asseliano y Sakmariano y una posterior disminución gradual hasta el Lopingiano. Los valores de los índices de aparición fueron más importantes que los de desaparición y se dieron en el Asseliano, mientras que las mayores desapariciones se observaron en el Capitaniano y en menor medida en el Sakmariano. Por otra parte, las esporas y los granos de polen presentan algunas diferencias en la tendencia general de diversidad. Sin embargo, se aprecian diferencias en los patrones de aparición y desaparición. A pesar de los posibles sesgos, fundamentalmente relacionados con el esfuerzo de colecta, existe cierta coherencia entre la diversidad, los índices de apariciones y desapariciones y las fases climáticas propuestas para esa edad en la región. El cambio hacia un clima más templado ocurrido en el Pérmico inferior estaría asociado a un aumento en el número de géneros de palinomorfos mientras que el comienzo de una fase más árida estaría relacionado a una disminución en la diversidad.
\end{abstract}

Palabras clave: Brasil, Diversidad, Paleozoico, Palinología, Uruguay. 
Á. Beri, et al., 2018. Palynodiversity patterns and paleoclimatic changes in the late Paleozoic... Boletín Geológico y Minero, 129 (4): $599-614$

\author{
VERSIÓN ABREVIADA EN CASTELLANO
}

\title{
Introducción y metodología
}

Las fases climáticas propuestas por Limarino et al. (2014) para el Paleozoico superior en las cuencas del sur de Sudamérica son: 1) glacial (Viseano tardío-Bashkiriano temprano); 2) glacial terminal (Bashkiriano temprano-Cisuraliano temprano); 3) postglacial (Cisuraliano-Guadalupiano temprano); y 4) semiárida-árida (Guadalupiano tardío-Lopingiano). La evolución de la diversidad que se observa en las asociaciones palinológicas durante el Paleozoico tardío puede ser usada como herramienta para comprender los cambios en la vegetación provocados por los cambios climáticos pasados. Existen antecedentes de estudios previos en los que se ha analizado la diversidad palinológica en cuencas sudamericanas utilizando, tanto la riqueza de los géneros, como el número de apariciones y desapariciones de éstos en los diferentes intervalos de tiempo (Beri et al., 2011, 2013, 2015). Los resultados de esos análisis indican que el comportamiento de la diversidad y de las apariciones y desapariciones de los géneros es coherente con la evolución climática. El objetivo de la presente contribución es contrastar esa hipótesis utilizando otro tipo de análisis, incluyendo mayor número de muestras y abarcando una mayor distribución geográfica.

En este estudio, se utilizaron datos ya publicados relacionados con las palinofloras de las cuencas Paraná (Brasil y Uruguay), Parnaíba y Amazonas (Brasil) (Figuras 1, 2 y 3). La base de datos comprende 124 géneros de polen y esporas de edades comprendidas entre el Pennsylvaniano y el Lopingiano. Los criterios para la elección de la bibliografía fueron, que incluyesen datos sobre la ubicación litoestratigráfica clara y edad de las muestras, y que no tuviesen información repetida, es decir, que se tendió a incluir aquellos artículos que fuesen de revisión. Para la cuenca de Paraná en Brasil se usó la siguiente bibliografía: Ybert (1975), CazzuloKlepzig et al. (1980), Dias Fabricio (1981), Marques-Toigo et al. (1982, 1984), Picarelli et al. (1987), Souza et al. (1997, 2003, 2010a, 2010b); di Pasquo et al. (2003a, 2003b), lannuzzi et al. (2006), Premator et al. (2006), Souza (2006), Neregato et al. (2008), Mori y Souza (2010, 2012) y Boardman et al. (2012a, 2012b). Para la cuenca Paraná en Uruguay, se consideró Beri y Pecoits (2001), Beri et al. (2011, 2013) y Mautino et al. (1998a, 1998b, 1998c). Para la Cuenca Parnaíba se usó Dino et al. (2002) y Dino y Playford (2002). Finalmente, para la cuenca Amazonas se consideraron los artículos Playford y Dino (2000a, 2000b). En relación a las sinonimias, se actualizaron los géneros de los artículos anteriores al año 1997; para los datos posteriores a esa fecha se respetaron los criterios de los autores. Específicamente, el género Acanthotriletes se mantuvo como taxón válido, ya que no se pudo distinguir a qué especies correspondía la cita original (Tabla 1).

La diversidad fue estimada como el número de géneros presentes en cada intervalo con y sin el método range through (Cheetham y Deboo, 1963; Boltovskoy, 1988). Las tasas de aparición y desaparición per-capita de los diferentes taxones fue calculada de acuerdo a Foote (2000) y utilizando el paquete Paleotree para $R$ (Bapst, 2012). La diversidad taxonómica por intervalo de tiempo y los índices de aparición y desaparición de los taxones fue estimada para todo el conjunto de los esporomorfos y además teniendo en cuenta las esporas y los granos de polen por separado. También se analizaron cada uno de los diferentes grupos de polen como monosacados, bisacados, bisacados estriados y poliplicados.

Se consideró el número de localidades muestreadas, es decir áreas geográficas, las cuales no necesariamente corresponden al número de muestras.

\section{Resultados y discusión}

El análisis de los taxones a través de las diferentes edades expresado en la cantidad de géneros por intervalo de tiempo muestra que la mayor diversidad ocurre durante el Cisuraliano. Los máximos valores se alcanzan en el Asseliano y Sakamariano. El mayor incremento en el número de taxones se puede observar entre el Gzheliano y el Asseliano que pasan de 14 a 107 géneros (Figura 4). La diversidad declina hacia el fin del Cisuraliano, se mantiene estable durante el Guadalupiano y decrece en el Lopingiano. Por otra parte, las curvas de diversidad consideradas con y sin el método range through, muestran las mismas tendencias generales descritas más arriba.

El número de localidades muestreadas alcanza sus mayores valores en el Asseliano y el Sakmariano (13) y el menor valor en el Gzheliano (1) (Figura 4).

Los valores máximos correspondientes a las tasas de aparición son mayores que los de las desapariciones (Figura 5). En el Asseliano ocurren los máximos valores de aparición, mientras que los mayores índices de desaparición se observan en el Capitaniano y, en menor medida, en el Sakmariano.

Si se analizan las esporas y los granos de polen por separado, se aprecia que presentan algunas diferencias en los patrones de diversidad (Figura 6). Los números de diversidad máxima son comparables (53 y 54 , respectivamente), sin embargo, las esporas comienzan con un mayor número de géneros en el Moscoviano (37 géneros de esporas y 25 géneros de granos de polen). El número de taxones de granos de polen no varía 
Á. Beri, et al., 2018. Palynodiversity patterns and paleoclimatic changes in the late Paleozoic... Boletín Geológico y Minero, 129 (4): $599-614$

significativamente durante el Cisuraliano y el Guadalupiano, mientras que el número de géneros de esporas decrece claramente durante estas épocas.

Según lannuzzi (2013) la diversidad de los diferentes grupos en el registro de megafósiles vegetales en Brasil exhibe un aumento en el Asseliano/Artinskiano. En efecto, la aparición de las glossopteridales y de varios helechos constituye el evento denominado F2 (lannuzzi y Souza, 2005; lannuzzi, 2013). Esta tendencia parece ser consistente con la diversidad palinológica que es encontrada en el presente estudio. Sin embargo, el aumento de diversidad en el Wordiano/Wuchipingiano propuesto por lannuzzi (2013) no se observa en el registro palinológico. En Uruguay, a pesar de que fue descrita una paleoflora correspondiente a estratos pérmicos, no se han propuesto subdivisiones bioestratigráficas y no se han realizado análisis de diversidad.

Si se compara la evolución de la diversidad con las fases climáticas propuestas por Limarino et al. (2014) (Figura 4), se puede observar que el número de géneros aumenta hacia el inicio del Cisuraliano, cuando ocurre el cambio de la fase glacial terminal a la postglacial. El mayor valor en las tasas de desaparición se da especialmente en los granos de polen bisacados (Figura 7). Por otra parte, en el Guadalupiano temprano, cuando ocurre el pasaje de la fase postglacial a la semiárida, el número de géneros decrece y en el Capitaniano los valores de desaparición son altos.

Cabe señalar que existen diferencias en el número de hallazgos por unidad de tiempo considerado, como resultado de los diferentes esfuerzos de muestreo o debido al potencial de preservación del material palinológico. Por otra parte, hay una coincidencia bastante apreciable entre la curva de diversidad y la curva correspondiente al número de localidades muestreadas en cada edad. De acuerdo con Cascales et al. (2013), los sesgos de muestreo constituyen el factor más importante que debe tenerse en cuenta cuando se utilizan los datos de paleodiversidad para evaluar si las extinciones son reales o no. Al mismo tiempo, como ya fue mencionado en contribuciones previas (Beri et al., 2013, 2015) existen ciertas limitaciones cuando se emplean datos palinológicos aplicados a la comprensión de las dinámicas vegetacionales, como por ejemplo, las diferencias en la producción, dispersión, cercanía a las plantas parentales y potencial de preservación de los diferentes ambientes y tipos de esporomorfos. Según Birks y Line (1992), la riqueza palinológica no puede ser interpretada directamente como riqueza florística debido a varios sesgos, incluyendo las diferencias de representación y preservación del polen, la estructura vegetacional, el tamaño de la cuenca y el nivel de detalle en la identificación taxonómica. Probablemente en aquellas edades que hay menor esfuerzo de muestreo, como es el caso del Gzheliano y el Lopingiano, no se trate de una diversidad palinológica real. Por otra parte, otro problema surge cuando se trata de inferir las condiciones paleoecológicas a partir de los palinomorfos paleozoicos. Dado que el registro de polen y esporas encontrados en conexión biológica con macrofósiles es limitado, resulta difícil asignar afinidades botánicas a muchos palinomorfos. Además, muchos morfotipos diferentes pueden ser producidos por la misma planta (Lindström et al., 1997). Sin embargo, se pueden observar patrones generales que se repiten en las diferentes cuencas ubicadas en diferentes zonas geográficas, que podrían relativizar los sesgos mencionados anteriormente. Por lo tanto, la presente contribución puede ser un aporte válido como una aproximación inicial a la temática de la diversidad en el Paleozoico superior.

\section{Introduction}

In the late Paleozoic strata of South America many changes in palynological assemblages can be observed. Particularly in Brazil and Uruguay, palynofloras have been used for biostratigraphic zonation (Playford and Dino, 2000a, 2000b; Souza and Marques-Toigo, 2003; Souza, 2006; Beri et al., 2011; Mori and Souza, 2012). In addition, studies concerning the bio-horizons of appearance and disappearance, as well as the intervals of dominance of certain sporepollen taxa, have been presented for certain portions of Gondwana, especially for Indian basins (e.g., Tiwari, 1999a, 1999b), some of them highlighting morphological changes and evolutionary trends (e.g., Venkatachala et al., 1995). It is reasonable to think that the evolution of the diversity observed in palynological assemblages is due to vegetational changes, which, in turn, are related to climate changes.
Following this line of argument, the hypothesis of this study is that there must be a relationship between climate changes and sporomorph diversity.

For the late Paleozoic in the southern South American basins four paleoclimatic stages have been identified by Limarino et al. (2014): 1) glacial (late Visean-early Bashkirian); 2) terminal glacial (Bashkirian-earliest Cisuralian); 3) post-glacial (Cisuralian-early Guadalupian); and 4) arid-semi-arid (late Guadalupian-Lopingian). Previous studies have also analyzed Upper Paleozoic palynological diversity in these basins (Beri et al., 2011, 2013, 2015). The main results of these publications indicate that diversity, appearances and disappearances are consistent with post-glacial climatic amelioration and the beginning of an arid phase. This study is based on the hypothesis that the climatic signal could be important enough to be observed despite possible biases being related to, for example, taphonomic processes, palynomorph 
differential dispersal and heterogeneous criteria for taxonomic identification. The aim of this paper is to test this hypothesis using a different statistical approach based on Foote's appearance and disappearance rates (2000), as well as using a higher number of samples and a wider geographic range.

\section{Material and methods}

Paleozoic palynoflora of the Paraná (Brazil and Uruguay), Parnaíba and Amazon (Brazil) basins was analyzed (Figs. 1, 2 and 3). A database of 124 pollen and spore genera was elaborated from published data of the Pennsylvanian-Lopingian age. Database inclusion criteria was based on a precise litostratigraphic and age information of samples favouring the use of review papers in order to avoid repeating previously published data. For the Paraná Basin in Brazil the following literature was used: Ybert (1975), Cazzulo-Klepzig et al. (1980), Dias Fabricio (1981), Marques-Toigo et al. (1982, 1984), Picarelli et al. (1987), Souza et al. (1997, 2003, 2010a, 2010b); di Pasquo et al. (2003a, 2003b), lannuzzi et al. (2006), Premator et al. (2006), Souza (2006), Neregato et al. (2008), Mori and Souza $(2010,2012)$ and Boardman et al. (2012a, 2012b). For the Paraná Basin in Uruguay Beri and Pecoits (2001), Beri et al. $(2011,2013)$ and Mautino et al. (1998a, 1998b, 1998c) were considered. Dino et al. (2002) and Dino and Playford (2002) were used for the Parnaíba Basin. Finally, Playford and Dino (2000a, 2000b) were considered for the Amazon Basin.

Regarding the existence of synonyms, genera assignation was updated for articles prior to 1997, whilst the authors' criteria were followed for posterior publications. Specifically, the genus Acanthotriletes remained as a valid taxon since it was not possible to distinguish to which species the original citation corresponded to.

To build up the database, each morphogenus was assigned to the appropriate ages except for the Lopingian, which was included without taking into account its subdivisions. In the case that a genus is cited in the literature as being found in a particular epoch (say, Cisuralian), it was considered as being present throughout that epoch, i.e., in all of its stages (Table 1).

Palynological samples from the Paraná Basin in Uruguay are exclusively of Permian age. More specifically, these correspond to the Cisuralian and Guadalupian stages.

Taxa diversity per time interval was estimated as the number of genera present in each interval with

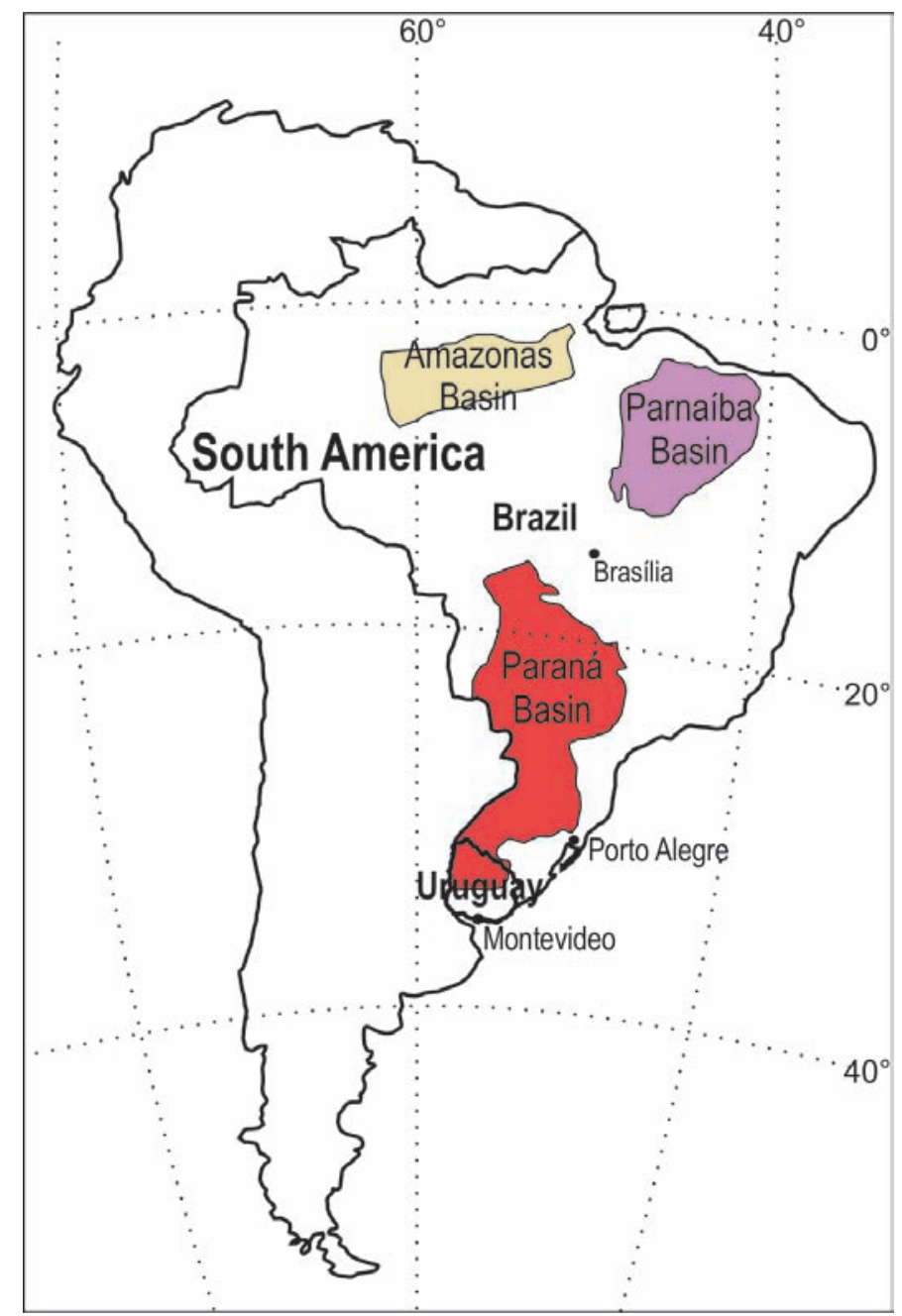

Figure 1. Geographic locations of the Paraná, Parnaíba and Amazon basins.

Figura 1. Ubicación geográfica de las cuencas Paraná, Parnaíba y Amazonas.

and without a range-through approach (Cheetham and Deboo, 1963; Boltovskoy, 1988). The rangethrough approach assumes that taxa occur in all the time intervals from the base of the interval they are first found in, until the end of the last interval they occur in.

Per-capita instantaneous appearance and disappearance rates of taxa were estimated following Foote (2000) using the R package Paleotree (Bapst, 2012), according to the following formulas:

appearances: $p=-\ln \left(\mathrm{N}_{\mathrm{b}} / \mathrm{N}_{\mathrm{t}}\right) / \Delta \mathrm{t}$

disappearances: $q=-\ln \left(\mathrm{N}_{\mathrm{b} t} / \mathrm{N}_{\mathrm{b}}\right) / \Delta \mathrm{t}$

where $\mathrm{N}_{\mathrm{bt}}$ is the number of taxon crossing both top 


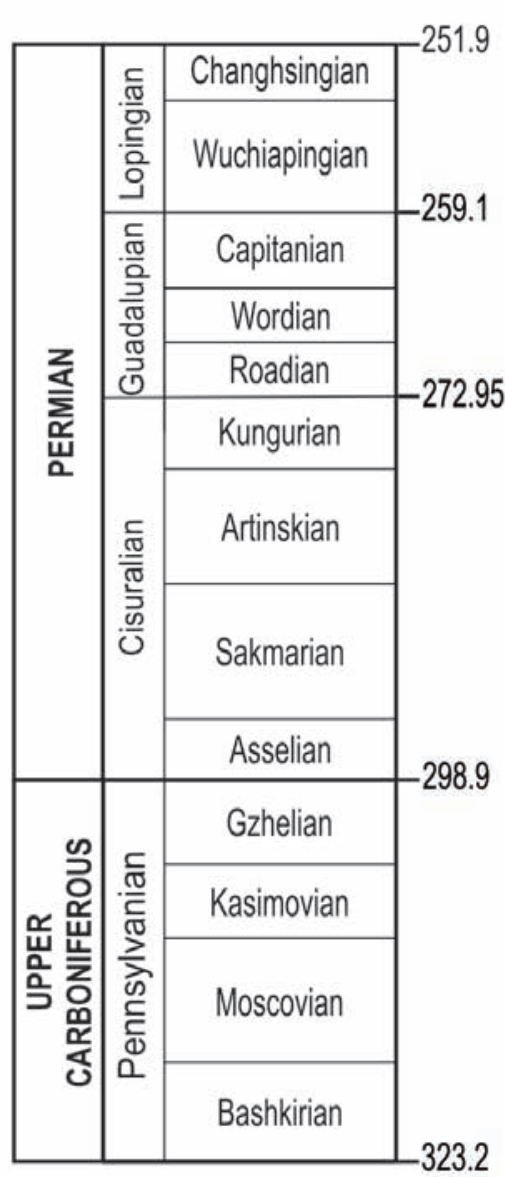

Amazonas Basin

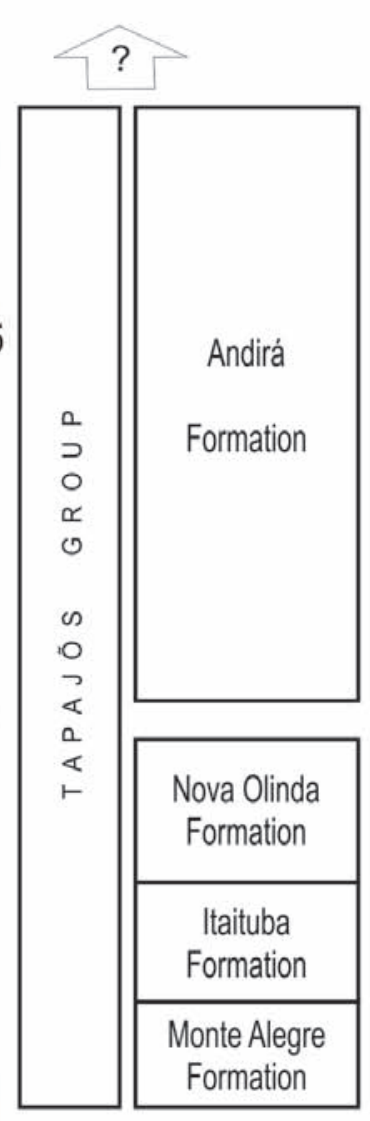

Parnaíba Basin

Paraná Basin

Figure 2. Pennsylvanian-Permian lithostratigraphic units of the main Brazilian intracratonic basins (Amazonas: according to Cunha et al., 2007; Parnaíba: Vaz et al., 2007; Paraná: Schneider et al., 1974, França and Potter, 1988; Milani et al., 2007; Holz et al., 2010).

Figura 2. Unidades litoestratigráficas de edad Pennsylvaniano-Pérmico correspondientes a las principales cuencas intracratónicas brasileñas (Amazonas: de acuerdo a Cunha et al., 2007; Parnaíba: Vaz et al., 2007; Paraná: Schneider et al., 1974, França and Potter, 1988; Milani et al., 2007; Holz et al., 2010).

and bottom boundaries; $\mathrm{N}_{\mathrm{t}}$ is the number of taxa crossing the top boundary and making their first appearance at this interval; $\mathrm{N}_{\mathrm{b}}$ is the number of taxa crossing the bottom boundary and making their last appearance in this interval.

Taxa diversity per time interval and per-capita instantaneous appearance and disappearance rates of taxa were estimated for all sporomorphs, and for different groups such as total pollen and total spore genera, as well as for monosaccate, bisaccate, bisaccate striate and polyplicate pollen genera.

In order to take into account the sampling effort of each time interval, the number of sampled localities (geographic areas) was considered. However, this number is not equivalent to the number of samples analyzed since there could be a large number of samples in a single locality or a low number of samples in a time interval with several localities.

\section{Results}

The analysis of taxa diversity through different stages, expressed as number of genera per time interval, shows that the highest diversity occurs during the Cisuralian and maximum values are reached in the Asselian and Sakmarian stages. The most important increase in taxa numbers can be observed 

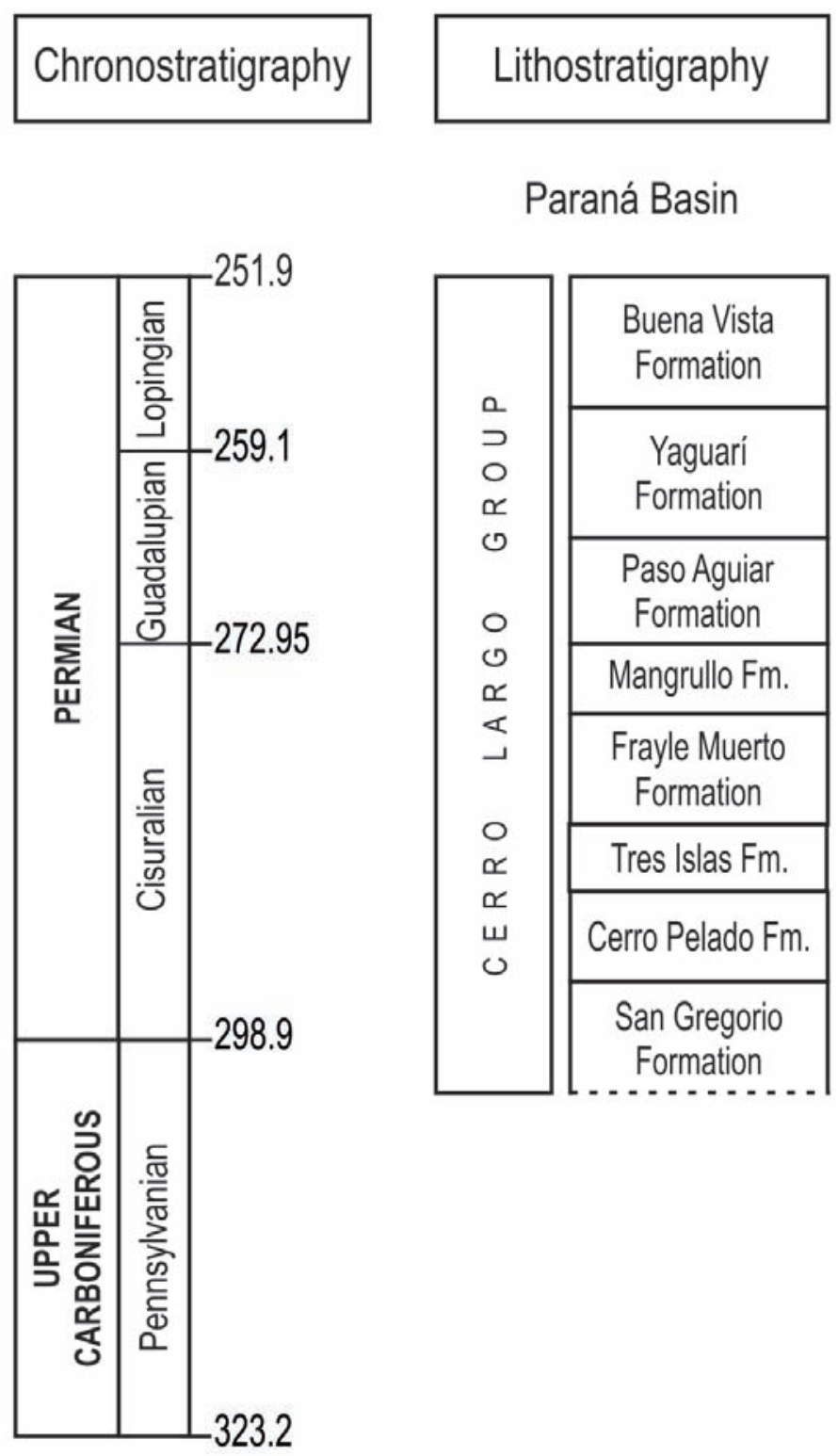

\begin{tabular}{|c|c|}
\hline \multirow{2}{*}{$\begin{array}{l}0 \\
\supset \\
0 \\
\alpha \\
0\end{array}$} & $\begin{array}{l}\text { Buena Vista } \\
\text { Formation }\end{array}$ \\
\hline & $\begin{array}{l}\text { Yaguarí } \\
\text { Formation }\end{array}$ \\
\hline \multirow{3}{*}{$\begin{array}{l}0 \\
0 \\
\propto \\
\varangle \\
\square\end{array}$} & $\begin{array}{l}\text { Paso Aguiar } \\
\text { Formation }\end{array}$ \\
\hline & Mangrullo Fm. \\
\hline & $\begin{array}{c}\text { Frayle Muerto } \\
\text { Formation }\end{array}$ \\
\hline \multirow{3}{*}{$\begin{array}{l}0 \\
\propto \\
\alpha \\
\text { జ } \\
u\end{array}$} & Tres Islas Fm. \\
\hline & Cerro Pelado Fm. \\
\hline & $\begin{array}{l}\text { San Gregorio } \\
\text { Formation }\end{array}$ \\
\hline
\end{tabular}

Figure 3. Pennsylvanian-Permian lithostratigraphic units of the Paraná Basin in Uruguay (based on de Santa Ana et al., 2006; Beri et al., 2011).

Figura 3. Unidades litoestratigráficas de edad PennsylvanianoPérmico correspondientes a la Cuenca Paraná en Uruguay (basado en de Santa Ana et al., 2006; Beri et al., 2011).

between the Gzhelian and the Asselian with changes from 14 to 107 genera. On the other hand, diversity declines between the Cisuralian and the Guadalupian, remains stable during the Guadalupian and decreases in the Lopingian. In addition, the curve of diversity calculated by using the range-through method shows the same general trend as describe above (Fig. 4). Furthermore, the number of sampled localities, which is not equivalent to the number of analyzed samples, reaches the highest values in the Asselian and Sakmarian (13) and the lowest values in the Gzhelian (1) (Fig. 4).

Analyses related to the quantification of appearance and disappearance of different taxa show that the maximum values of appearance rates are more important than those of disappearance. The maximum values of appearances occurred in the Asselian and the higher values of disappearances are observed in the Capitanian, and in a lesser extent, in the Sakmarian (Fig. 5).

Spores and pollen grain diversity were independently analyzed and some differences in the diversity patterns can be appreciated (Fig. 6). Maximum diversity numbers are similar (53 and 54 genera, respectively), however, spores show a higher number of genera (37) in the Moscovian in comparison to pollen grains (25). The number of pollen grain genera does not vary significantly during the Cisuralian and Guadalupian, whilst the number of spore genera clearly decreases throughout these epochs (Fig. 6).

Differences in appearance rates of spores and pollen grains can be easily noticed, however, both are present the maximum values in the Asselian (Fig.6). Spores possess a lower appearance rate than pollen grains in the Kasimovian and Artinskian, and no occurrences are recorded in the Roadian. Disappearance rates of spores and pollen grains also have certain differences. Spores present a low disappearance rate in the Kasimovian whilst pollen grains do not exhibit disappearances in this age. Moreover, spores and pollen grains have similar disappearance rates in the Sakmarian and higher disappearance rates in the Kungurian but a lower disappearance rate in the Capitanian (Fig. 6).

Furthermore, diversity of the most important groups of pollen grains (monosaccate, bisaccate, bisaccate striate and polyplicate grains) was independently analyzed. The results indicate that higher appearance rates occur in the Asselian and secondarily, in the Kasimovian, except in the case of bisaccate striate grains whose disappearance rate is slightly higher in the Artinskian than in the Kasimovian. In addition, appearances of monosaccate pollen also take place in the Artinskian whilst appearances of bisaccate grains are recorded in the Roadian. Disappearances are more significant in the Capitanian. Disappearances in the Kungurian are very scarce for all groups, except for bisaccate grains. It should be noted that monosaccate and bissacate have a pretty high disappearance rate in the Capitanian (Fig. 7).

Finally, when diversity trends are compared with the climatic stages proposed by Limarino et al. (2014) 
Á. Beri, et al., 2018. Palynodiversity patterns and paleoclimatic changes in the late Paleozoic... Boletín Geológico y Minero, 129 (4): $599-614$

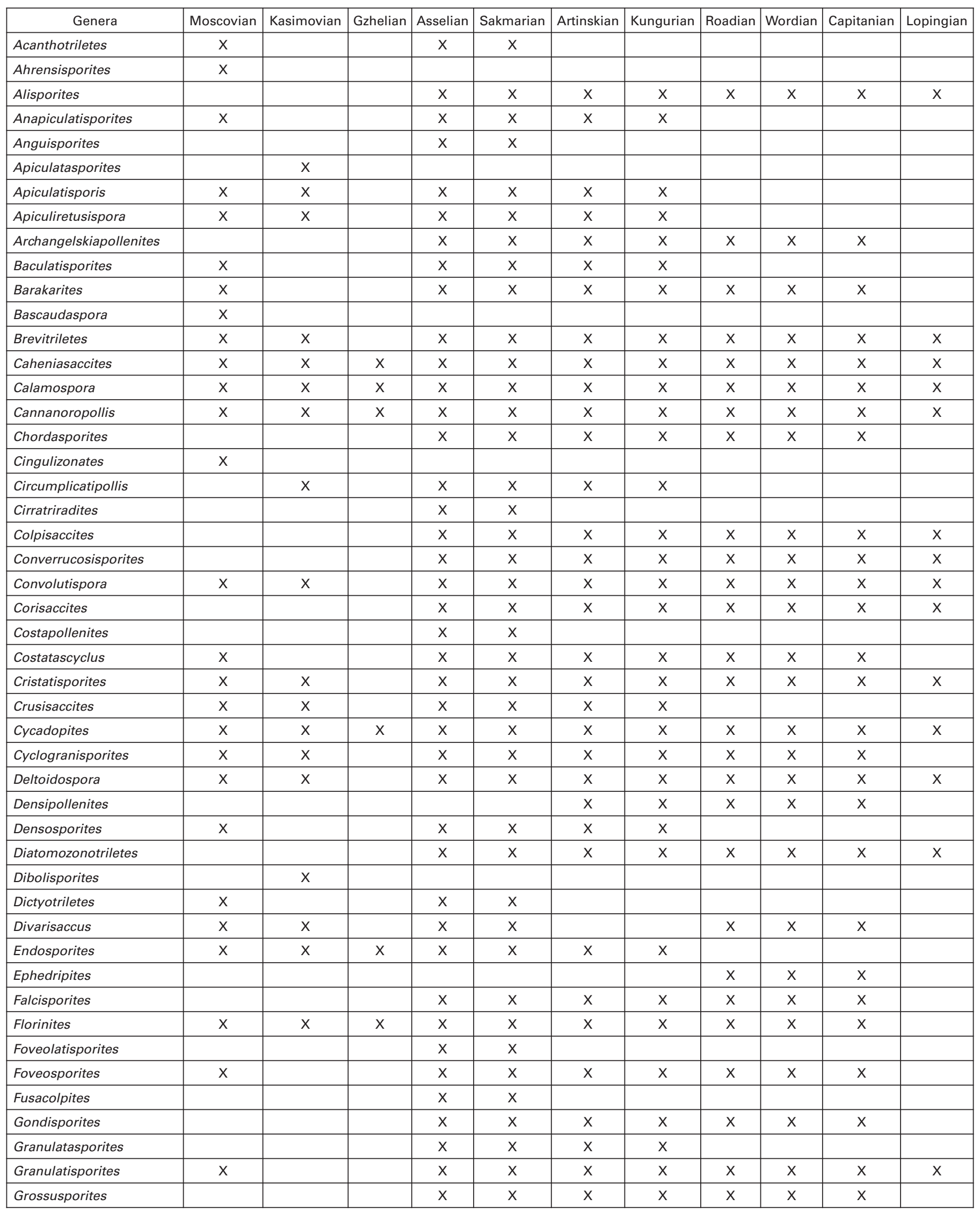


Á. Beri, et al., 2018. Palynodiversity patterns and paleoclimatic changes in the late Paleozoic... Boletín Geológico y Minero, 129 (4): $599-614$

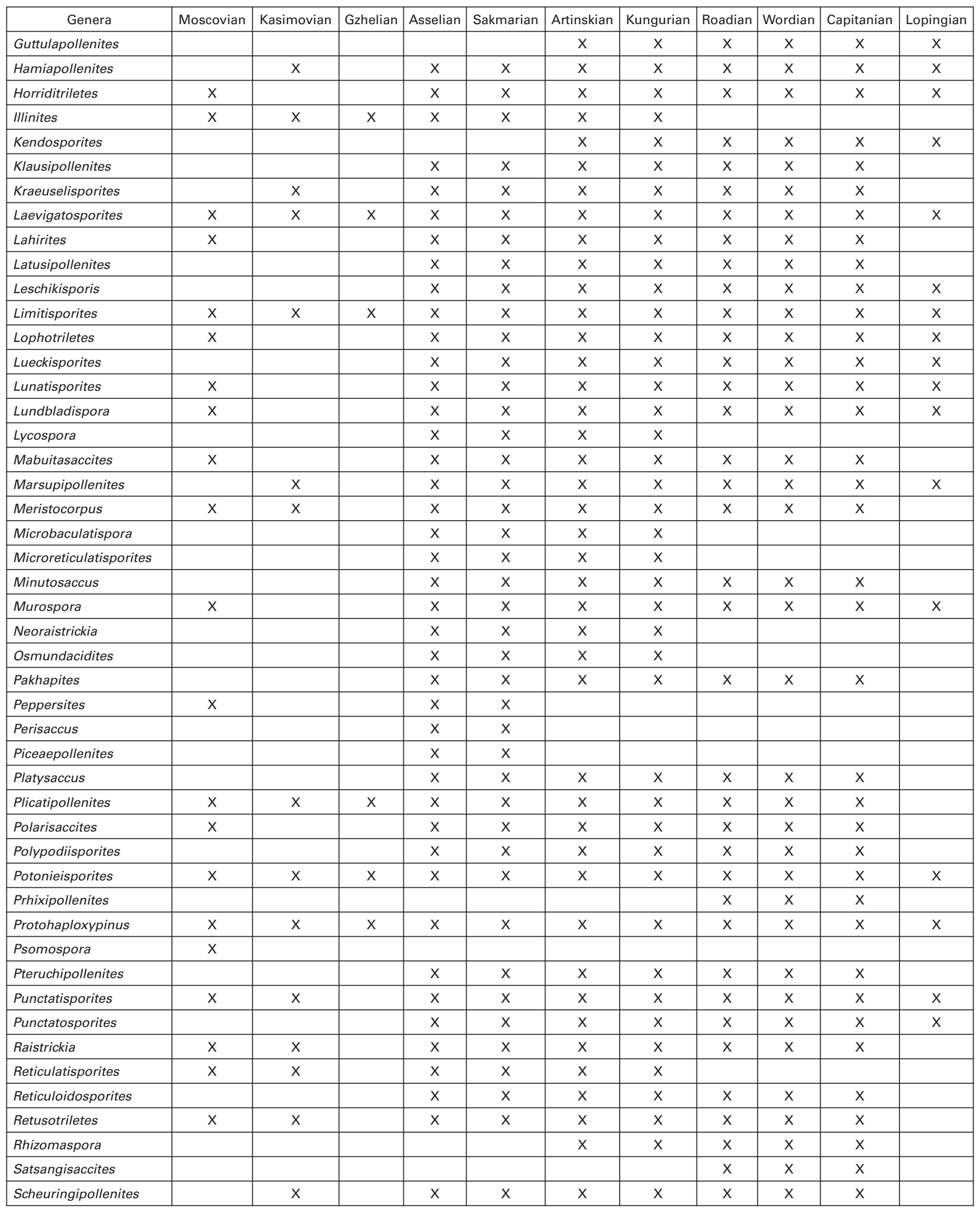


Á. Beri, et al., 2018. Palynodiversity patterns and paleoclimatic changes in the late Paleozoic... Boletín Geológico y Minero, 129 (4): $599-614$

\begin{tabular}{|c|c|c|c|c|c|c|c|c|c|c|c|}
\hline Genera & Moscovian & Kasimovian & Gzhelian & Asselian & Sakmarian & Artinskian & Kungurian & Roadian & Wordian & Capitanian & Lopingian \\
\hline Scutasporites & & & & & & $x$ & $x$ & $x$ & $x$ & $\mathrm{x}$ & \\
\hline Secarisporites & $x$ & & & & & & & & & & \\
\hline Staurosaccites & & & & $x$ & $x$ & $x$ & $x$ & $x$ & $x$ & $x$ & $x$ \\
\hline Stellapollenites & & & & $x$ & $x$ & $x$ & $x$ & $x$ & $x$ & $x$ & \\
\hline Stenozonotriletes & $x$ & $x$ & & $x$ & $x$ & $x$ & $x$ & $x$ & $x$ & $x$ & \\
\hline Striatoabieites & $x$ & & & $x$ & $x$ & $x$ & $x$ & $x$ & $x$ & $x$ & $x$ \\
\hline Striatopodocarpites & $x$ & & & $x$ & $x$ & $x$ & $x$ & $x$ & $x$ & $x$ & $x$ \\
\hline Striatosporites & $x$ & & & & & $x$ & $x$ & $x$ & $x$ & $x$ & $x$ \\
\hline Striomonosaccites & $x$ & $x$ & $x$ & $x$ & $x$ & $x$ & $x$ & $x$ & $x$ & $x$ & $x$ \\
\hline Taeniasporites & $x$ & & & $x$ & $x$ & & & & & & \\
\hline Tornopollenites & & & & & & $x$ & $x$ & $x$ & $x$ & $x$ & \\
\hline Tuberculatosporites & & & & $x$ & $x$ & & & & & & \\
\hline Tuberisaccites & & & & $x$ & $x$ & $x$ & $x$ & $x$ & $x$ & $x$ & \\
\hline Vallatisporites & $x$ & $x$ & & $x$ & $x$ & $x$ & $x$ & $x$ & $x$ & $x$ & $x$ \\
\hline Velamisporites & $x$ & $x$ & & & & & & & & & \\
\hline Verrucosisporites & $x$ & $x$ & & $x$ & $x$ & $x$ & $x$ & $x$ & $x$ & $x$ & \\
\hline Verticipollenites & $x$ & & & & & & & & & & \\
\hline Vesicaspora & $x$ & $x$ & $x$ & $x$ & $x$ & $x$ & $x$ & $x$ & $x$ & $x$ & $x$ \\
\hline Vestigisporites & & & & $x$ & $x$ & & & & & & \\
\hline
\end{tabular}

Table 1. Distribution of sporomorph genera in the Middle Pennsylvanian-Lopingian time intervals for the Paraná, Parnaíba and Amazon basins.

Tabla 1. Distribución de géneros de esporomorfos a lo largo de los intervalos de tiempo Pennsylvaniano Medio-Lopingiano para las cuencas Paraná, Parnaíba y Amazonas.

(Fig. 4), it is possible to observe that the number of genera increase at the beginning of the Cisuralian, which coincides with the climate change that took place from the terminal glacial to post-glacial stage. Moreover, the highest appearance rates are registered, in particular, for the bisaccate pollen grains (Fig. 7). On the other hand, in the early Guadalupian, when climate changes occurred from the Postglacial to the Semiarid-Arid Stage, the number of genera decrease; particularly, disappearance rates show high values during the Capitanian.

\section{Discussion}

Different biostratigraphic proposals for these strata are based on changes of palynofloral and the relative importance of taxa or groups of taxa in different ages. In this context, it is relevant to analyze the diversity of these assemblages in order to understand the dynamics of palynoflora. In the Paraná Basin in Brazil and the Amazon Basin, Carboniferous palynological zones are characterized by the dominance of spores and monosaccate pollen (Playford and Dino, 2000a, 2000b; Souza and Marques-Toigo, 2003; Souza, 2006; lannuzzi et al., 2010). According to the results of this study, spore diversity is also higher than pollen grain diversity. In addition, among different groups of pollen grains, monosaccate genera diversity is the most abundant. In lower Permian zones, pollen grains are, in general terms, more abundant than spores and taeniate and polyplicate pollen frequency rises. In this 


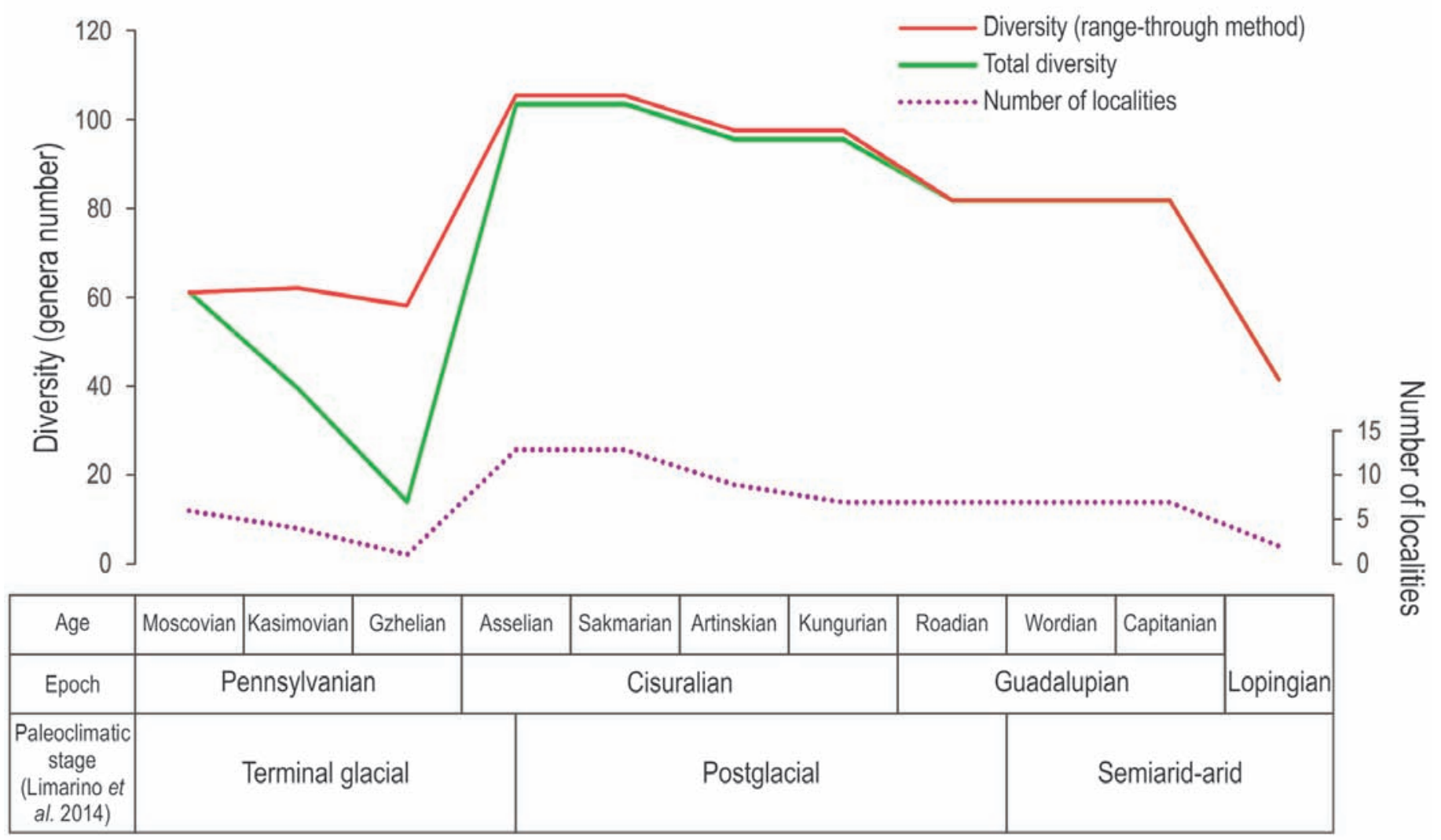

Figure 4. Changes in palynological diversity from the Middle Pennsylvanian to the Lopingian. Curves of total diversity and diversity calculated by using the range-through method for spores and pollen grains and number of localities per time interval are shown.

Figure 4. Cambios en la diversidad palinológica desde el Pennsylvaniano Medio al Lopingiano. Se muestran las curvas de diversidad total y diversidad calculada utilizando el método range-through para las esporas y los granos de polen, así como también, el número de localidades por intervalo de tiempo considerado.

study, spore diversity is similar to pollen diversity, and monosaccate, bisaccate, bisaccate striated, and polyplicate pollen increase. Finally, at the end of the Cisuralian and during the Guadalupian, palynozones are dominated by taeniate and polyplicate grains. According to these results, during that interval pollen grains are more represented than spores and bisaccate striated grains slightly increase. However, polyplicate grains possess a low diversity that remains stable until the Lopingian. In the Paraná Basin in Uruguay there are no carboniferous palynological records, however, trends observed during the Permian can be correlated with those registered in Brazil (Beri et al., 2011). During the studied time interval no major rates of disappearance occur, therefore palynological assemblages suggest a gradual taxonomic substitution pattern. Diversity clearly rises at the beginning of the Cisuralian. Relevant processes of appearances are registered in the Asselian, mainly due to a higher record of pollen grains, especially bisaccate and polyplicate grains. Therefore, in general terms, pollen grains are responsible for the taxo- nomic novelty on the assemblages since spores show lower appearance rates than pollen grains. These diversity trends are consistent with those observed in the biostratigraphic proposals. For example, the Vittatina costabilis Biozone (respectively for the Paraná and Amazon basins) and Cristatisporites inconstans-Vittatina saccata Biozone (Paraná Basin, Uruguay) for the beginning of the Permian are characterized by the appearance of the genus Vittatina (Souza and Marques-Toigo, 2003; Beri et al., 2011).

According to lannuzzi (2013), the diversity of different megafloral groups in Brazil exhibit peaks in the Asselian/Artinskian. This trend would be consistent with the palynological diversity observed in this study. In addition, the appearance of glossopoterids followed by ferns constitutes the floristic event denominated F2 and the transgressive event T2 (lannuzzi and Souza, 2005; lannuzzi, 2013). However, the peak in diversity in the Wordian/Wuchiapingian proposed by lannuzzi (2013) is not observed in the palynological record. Although a quite diverse paleoflora is described for Uruguay, no diversity analysis 


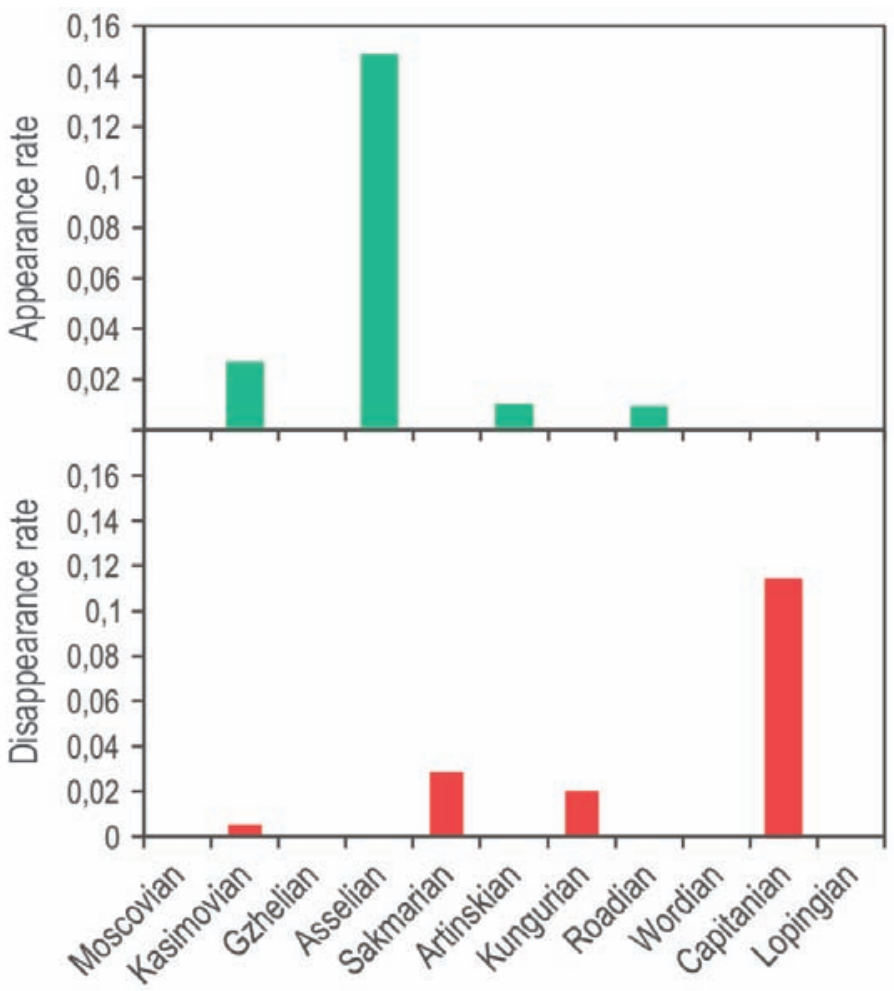

Figure 5. Per-capita rates of appearance and disappearance for spores and pollen grains.

Figura 5. Tasas de aparición y desaparición per-capita para las esporas y los granos de polen.

has been conducted and no biostratigraphic subdivision has been proposed.

Taking into account the regional climatic stages proposed by Limarino et al. (2014), a relationship between different climatic phases and diversity trends throughout the studied period can be observed. Thus, the evolution of diversity, as well as the appearance and disappearance rates, seems to be related to climate changes. The most parsimonious explanation would be that this relationship is due to the response of vegetation to climate changes. It should be noted that the appearance rate represent the first records or taxonomic novelty on a certain moment. However, in the case of disappearance rates the last records are considered and therefore vegetational changes must be interpreted to occur in the subsequent interval. At the beginning of the Cisuralian, an increase in diversity and the highest appearance rates are registered, considering the total amount of taxa as well as different palynological groups. These observations are consistent with the climatic amelioration observed at the Postglacial Stage, characterized by a temperate/cold humid climate. On the other hand, in the Roadian, just before the beginning of the arid-semi-arid stage according to Limarino et al. (2014), there is a decline in the number of taxa and a small increase in the appearance rate, especially in pollen grains. In addition, during the Kungurian, there is an apparent increase in the disappearance rate, mainly in spores. These events can be expected due to aridification processes, and in such conditions, plant diversity is mainly represented by mesophilous and xerophytic plants (bisaccate and striate pollen grains). Thus, at this time the hydrophilic vegetation has been partly replaced by mesophilous and xerophytic plant communities.

It should be noted that the database presents differences in the number of findings for each time interval considered, either as a result of differences in the sampling effort or the potential for fossilization of palynological material. On the other hand, there is a relatively important coincidence between diversity curve and the number of sampled localities for each age. According to Cascales et al. (2013), sampling bias is a major factor that must be taken into account when paleodiversity data is used to determine whether biological mass extinctions were a reality or not. On the contrary, and as was previously pointed out by Beri et al. $(2013,2015)$, there are some limitations when pollen and spores are used to study vegetation dynamics, for example: differences in pollen production, degree of dispersion, closeness to parental plants and preservational potential of different depositional environments and sporomorphs types.

In addition to this, palynological (pollen and spores) richness, as coined by Birks and Line (1992), cannot be interpreted directly as floristic richness due to a number of further biases, such as differences in pollen representation and preservation, vegetation structure, basin size, and taxonomic accuracy in the identification of pollen and spores. To illustrate one of these biases for the case of this study, we could observe that the notorious difference in the number of taxa between the Gzhelian and the Asselian could be explained by the difference in the number of sampled localities. However, the fact that the number of localities is not necessarily equivalent to the number of samples must be taken into account, for example, in the time intervals where there is a less sampling effort, such as in the Gzhelian and Lopingian, the registered diversity could not be an actual palynological diversity. Another problem arises when it comes to inferring paleoecological conditions from Paleozoic palynomorphs. Since there is a limited record of pollen and spores in biological connection with macrofossils, it is difficult to assign botanical affinities to many palynomorphs. Moreover, many different 


\section{A- Spores}

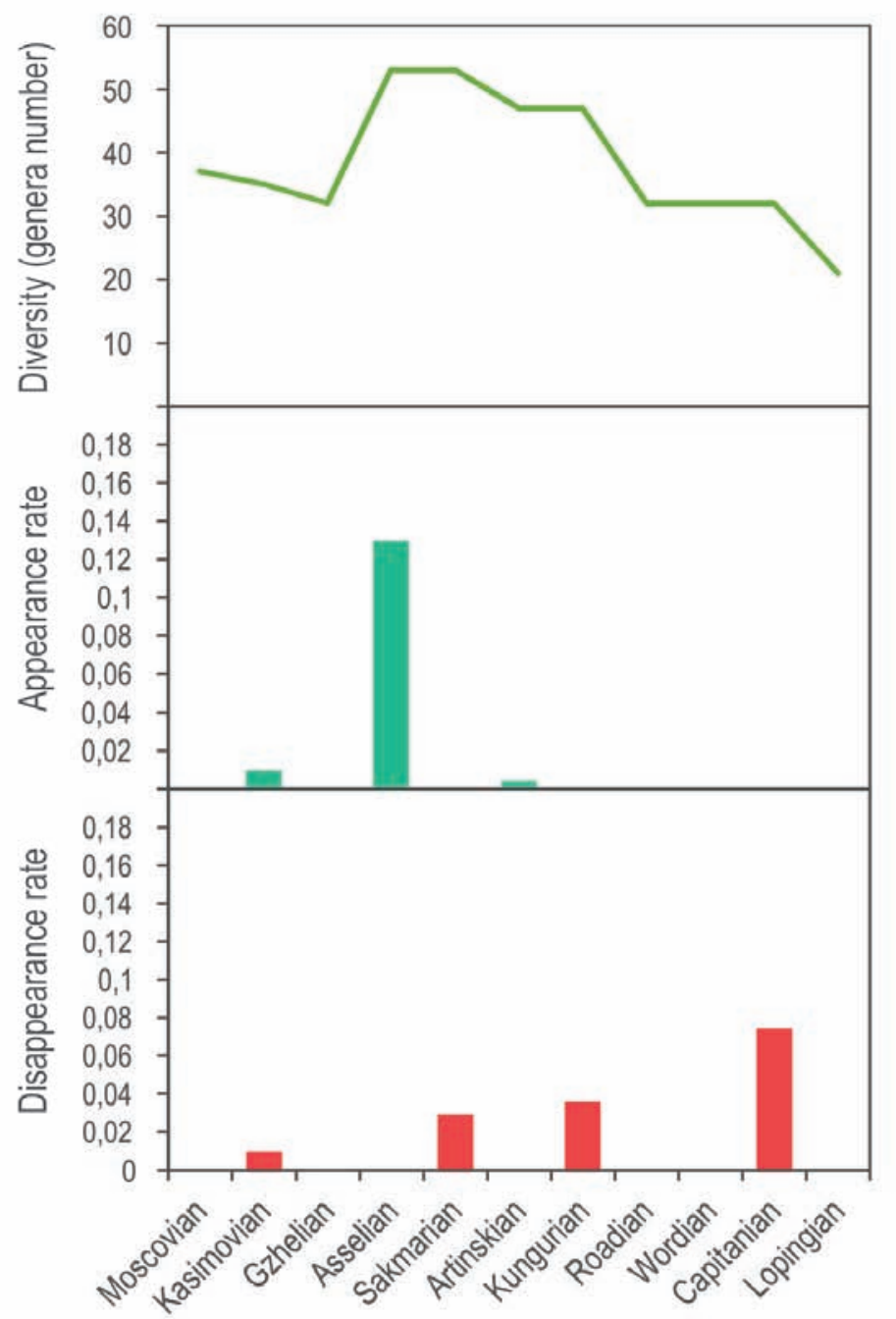

\section{B- Pollen grains}

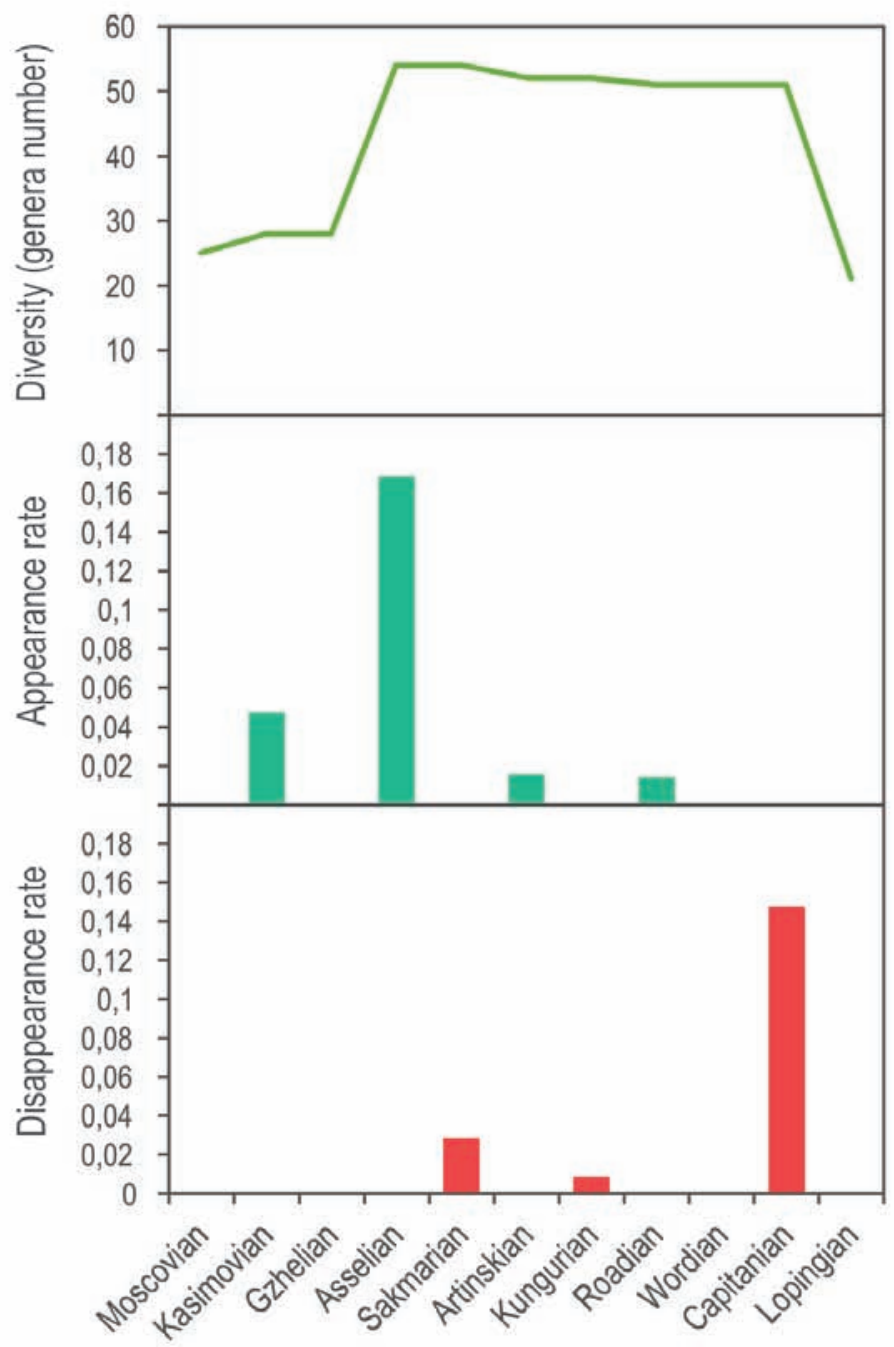

Figure 6. Diversity calculated by using the range-through method and per-capita rates of appearance and disappearance for spores (A) and pollen grains (B).

Figura 6. Diversidad calculada utilizando el método range-through y tasas de aparición y desaparición per-capita para las esporas (A) y los granos de polen $(B)$.

morphotypes can be produced by the same plant (Lindström et al., 1997). However, recurring general patterns occur and are strong enough to be observed in different basins of different geographical locations which partially relativize the biases mentioned above. Therefore, this research can be considered as a valid initial approximation to the study of diversity in the late Paleozoic.

\section{Conclusions}

The analysis of taxa diversity throughout different stages, expressed as number of genera per time interval, shows that the highest diversity occurs during the Cisuralian and maximum values are reached in the Asselian and Sakmarian.

The highest appearance rates occurred in the Asselian, whilst the highest disappearance rates are observed in the Capitanian and secondarily in the Sakmarian. Spores and pollen grain diversity were independently analyzed and both groups presented the same general diversity trends. However, appearance and disappearance patterns exhibit some differences.

A correlation between different climatic phases 


\section{A- Monosaccate pollen}

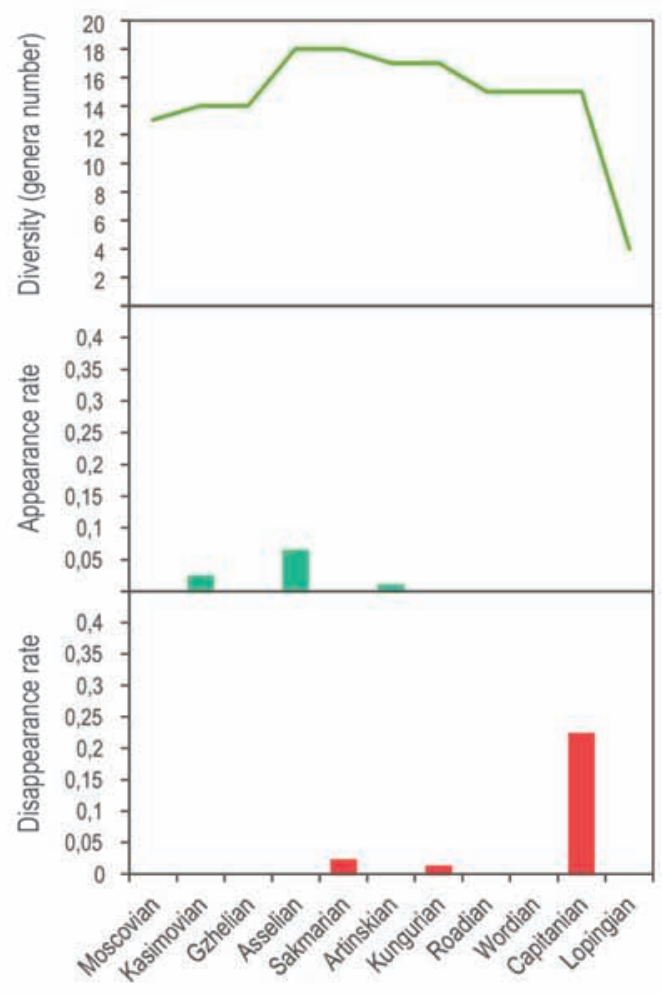

C- Bisaccate striate pollen

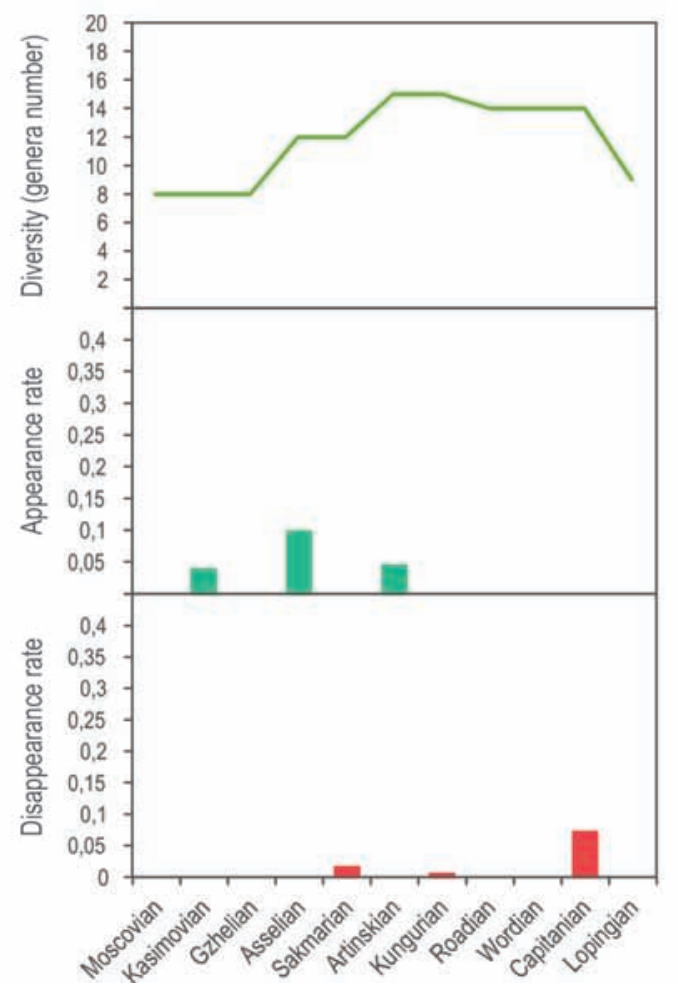

\section{B- Bisaccate pollen}

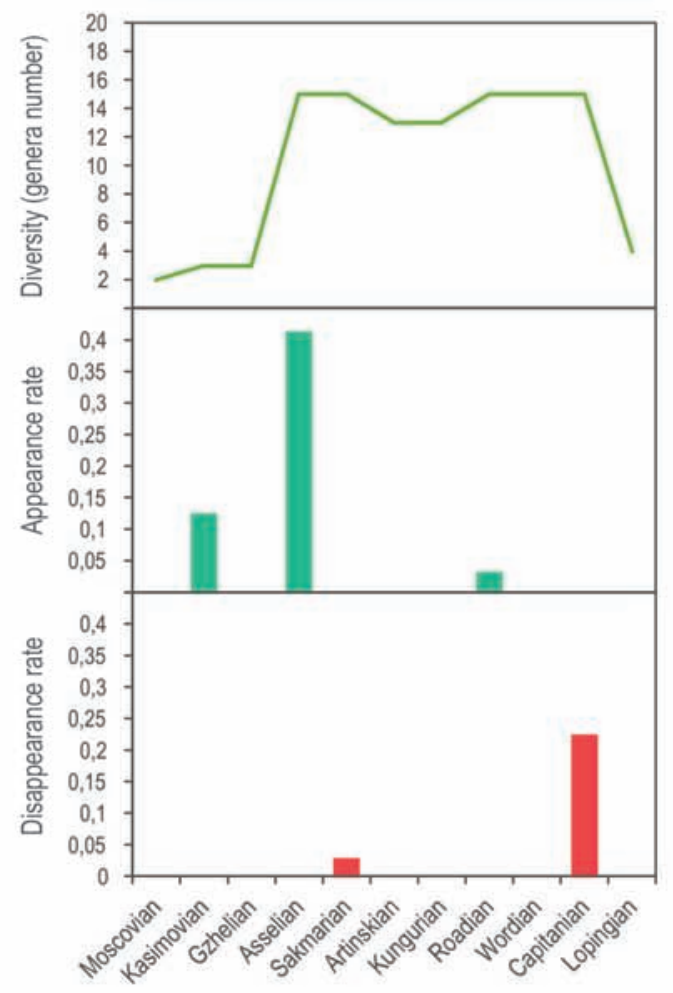

D- Polyplicate pollen

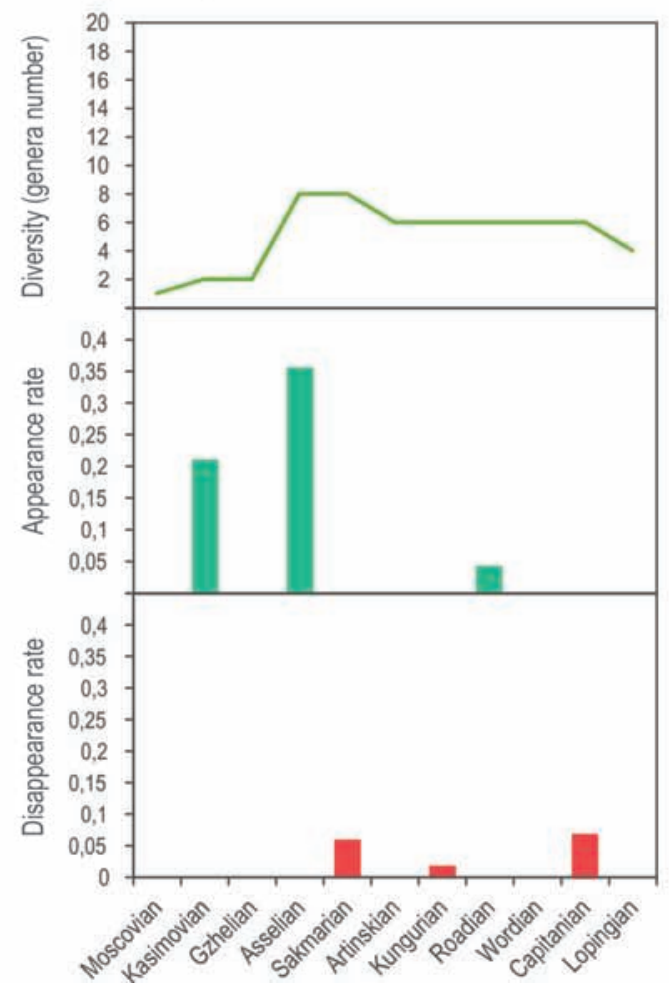

Figure 7. Diversity calculated by using the range-through method and per-capita rates of appearance and disappearance for monosaccate $(A)$, bisaccate $(B)$, bisaccate striate (C) and polyplicate (D) pollen grains.

Figura 7. Diversidad calculada utilizando el método range-through y tasas de aparición y desaparición per-capita para los granos de polen monosacados $(A)$, bisacados $(B)$, bisacados estriados $(C)$ y poliplicados $(D)$. 
proposed for the Upper Paleozoic in Western Gondwana and diversity trends throughout the studied period can be observed. The climatic amelioration in the lower Permian would therefore be associated with an increase in the number of sporomorphs genera whilst the beginning of the more arid phase would be related to a decrease in diversity.

Biases such as the preservational potential of palynological material and differences in the sampling effort must be taken into account when interpreting the results. For this reason, it is necessary to increase the database including other geographical locations in order to assess whether the diversity patterns observed in this study could apply to a larger geographical area of Gondwana.

\section{Acknowledgements}

This research was funded the CSIC I+D (2014) in Uruguay and the CNPq 461628/2014-7 in Brazil.

\section{References}

Bapst, D.W. 2012. paleotree: an R package for paleontological and phylogenetic analyses of evolution. Methods in Ecology and Evolution, 3 (5), 803-807.

Beri, Á. and Pecoits, E. 2001. Palinología y sedimentología de la Formación Melo (Pérmico), en la cañada "El Barón”, Depto. de Cerro Largo, Uruguay. Ameghiniana, 38 (4), 419-428.

Beri, Á., Gutiérrez, P. and Balarino, L. 2011. Palynostratigraphy of the Late Paleozoic of Uruguay, Paraná Basin. Review of Paleobotany and Palynology, 167 (1), 16-29.

Beri, Á., Gutiérrez, P.R. and Balarino, M.L. 2015. The late Paleozoic palynological diversity in southernmost Paraná (Uruguay), Claromecó and Paganzo basins (Argentina), Western Gondwana. Journal of South American Earth Sciences, 64 (1), 183-189.

Beri, Á., Mori, A.L.O., Tejera, L., Martínez-Blanco, X. and Souza, P. 2013. Palynodiversity patterns from Cisuralian deposits of southmost Paraná Basin, Western Gondwana. Bulletin of the New Mexico Museum of Natural History and Science, 60, 17-21.

Birks, H.J.B. and Line, J.M., 1992. The use of rarefaction analysis for estimating palynological richness from quaternary pollen-analytical data. The Holocene, 2 (1), 1-10.

Boardman, D., lannuzzi, R., Alves de Souza, P. and da Cunha Lopes, R. 2012a. Paleobotanical and palynological analysis of Faxinal Coalfield (Lower Permian, Rio Bonito Formation, Paraná Basin), Rio Grande Do Sul, Brazil. International Journal of Coal Geology, 102, 12-25.

Boardman, P., Souza, P., lannuzzi, R. and Mori, L.O. 2012b. Paleobotany and palynology of the Rio Bonito Formation (Lower Permian, Paraná Basin, Brazil) at the Quitéria outcrop. Ameghiniana, 49 (4), 451-472.
Boltovskoy, D. 1988. The range-through method and the first-last appearance data in paleontological surveys. Journal of Paleontology, 62, 157-159.

Cascales, B., Miñana, A., Cleal, C.J. and Diez, J.B. 2013. What is the best way to measure extinction? A reflection from the palaeobotanical record. Earth Science Reviews, $124,126-147$.

Cazzulo-Klepzig, M., Guerra-Sommer, M. and MarquesToigo, M. 1980. Estudo macro e microflorístico do grupo Itararé (Bacia do Paraná), Rio Grande do sul. XXXI Congresso brasileiro de geologia, Camboriú, Santa Catarina, 6, 3027-3036.

Cheetham, A.H. and Deboo, P.B. 1963. A numerical index for biostratigraphic zonation in the mid-Tertiary of the eastern Gulf. Gulf Coast Association of Geological Societies Transactions, 13, 139-147.

Cunha, P.R.C., Melo, J.H.G. and Silva, O.B. 2007. Bacia do Amazonas. Boletim de Geociências da Petrobrás, 15 (2), 227-251.

de Santa Ana, H., Veroslavsky, G., Fulfaro, V. and Rossello, E. 2006. Cuenca Norte: evolución tectónica y sedimentaria. In: Veroslavsky, G., Ubilla, M. and Martínez, S. (eds.), Cuencas Sedimentarias de Uruguay: Geología, Paleontología \& Recursos Naturales. DIRAC. Montevideo, 209-244.

Dias-Fabrício, M.E. 1981. Palinologia da Formação Rio Bonito na área de Gravataí Morungava, Rio Grande do Sul. Pesquisas, 14, 69-129.

Dino, R. and Playford, G. 2002. Stratigraphic and palaeoenvironmental significance of Pennsylvanian (Upper Carboniferous) palynofloras from the Piauí Formation, Parnaíba Basin, Brazil. Paleontological Research, 6 (1), 23-40.

Dino, R., Antonioli, L. and Braz, S.M.N. 2002. Palynological data from the Trisidela Member of Upper Pedra de Fogo Formation ("Upper Permian") of the Parnaíba Basin, northeastern Brazil. Revista Brasileira de Paleontologia, 3, 24-35.

di Pasquo, M., Azcuy, C.L. and Souza, P.A. 2003a. Palinología del Carbonífero Superior del Subgrupo Itararé em Itaporanga, Cuenca Paraná, Estado de São Paulo, Brasil: Parte 1. Sistemática de esporas y paleofitoplancton. Ameghiniana, 40 (3), 277-296.

di Pasquo, M., Azcuy, C.L. and Souza, P.A. 2003b. Palinología del Carbonífero Superior del Subgrupo Itararé em Itaporanga, Cuenca Paraná, Estado de São Paulo, Brasil: Parte 2. Sistemática de pólen y significado paleoambiental y estratigráfico. Ameghiniana, 40 (3), 297-313.

Foote, M. 2000. Origination and extinction components of taxonomic diversity: general problems. In: Erwin, D.H. and Wing, S.L. (eds.), Deep Time: Paleobiology's Perspective. The Paleontological Society, Kansas, 74-102.

França, A.B. and Potter, P.E. 1988. Estratigrafia, ambiente deposicional e análise de reservatório do Grupo Itararé (Permocarbonífero), Bacia do Paraná (parte 1). Boletim de Geociências da Petrobrás, 2 (2/4), 147-191.

Holz, M., França, A.B., Souza, P.A., lannuzzi, R. and Rohn, R. 2010. A stratigraphic chart of the Late Carboniferous/Permian succession of the eastern border 
of the Paraná Basin, Brazil, South America. Journal of South American Earth Sciences, 29 (2), 381-399.

lannuzzi, R. 2013. The Carboniferous - Permian Floral Transition in the Paraná Basin. Bulletin of the New Mexico Museum of Natural History and Science, 60, 132 $-136$.

lannuzzi, R. and Souza, P. 2005. Floral succession in the Lower Permian deposits of the Brazilian Paraná Basin: An up-to-date overview. New Mexico Museum of Natural History and Science, 30, 144-149.

lannuzzi, R., Souza, P.A. and Holz, M. 2010. Stratigraphic and paleofloristic record of the Lower Permian post-glacial succession in the southern Brazilian Paraná Basin. In: López-Gamundí, O.R. and Buatois, L.A. (eds.), Late Paleozoic glacial Events and Postglacial Transgressions in Gondwana. Geological Society of America Special Paper, 468, 113-132.

lannuzzi, R., Scherer, C.M.S., Souza, P.A., Holz, M., Caravaca, G., Adami-Rodrigues, K., Tybusch, G.P., Souza, J.M., Smaniotto, L.P., Fischer, T.V., Silveira, A.S., Lykawka, R., Boardman, D.R. and Barboza, E.G. 2006. Afloramento Morro do Papaléo, Mariana Pimentel, RS - Registro ímpar da sucessão sedimentar e florística pós-glacial do Paleozóico da Bacia do Paraná. In: Winge, M., Schobbenhaus, C., Berbert-Born, M., Queiroz, E. T., Campos, D. A., Souza, C. R. G. and Fernandes, A.C.S (eds.), Sítios Geológicos e Paleontológicos do Brasil. Serviço Geológico do Brasil - CPRM, Volumen 2, Brasilia, 321-336.

Limarino, C.O., Césari, S.N., Spalletti, L.A., Taboada, A.C., Isbell, J.L., Geuna, S. and Gulbranson, E.L. 2014. A paleoclimatic review of southern South America during the late Paleozoic: A record from icehouse to extreme greenhouse conditions. Gondwana Research, 25 (4), 13961421.

Lindström, S., McLoughlin, S. and Drinnan, A.N. 1997. Instraspecific variation of taeniate bisaccate pollen within Permian Glossopterid sporangia, from the Prince Charles Mountains, Antarctica: International Journal Plant Sciences, 158 (5), 673-684.

Marques-Toigo, M., Dias-Fabricio, M.E. and CazzuloKlepzig, M. 1982. Palynological and paleoecological characterization of Santa Rita Coalfield, Rio Grande do Sul, Paraná Basin, Lower Permian of Southern Brazil. Acta Geológica Leopoldensia, 16, 55-74.

Marques-Toigo, M., Dias-Fabricio, M.E. and CazzuloKlepzig, M. 1984. A sucessão da microflora nas camadas de carvão da bacia carbonífera de CharqueadasFormación Rio Bonito, RS, Brasil. Boletim IG-USP, 15, 65-72.

Mautino, L.R., Anzótegui, L.M. and Vergel, M.M. 1998a. Palinología de la Formación Melo (Pérmico Inferior) en Arroyo Seco, Departamento Rivera - República Oriental del Uruguay. Parte IV: Esporas. Ameghiniana, 35 (1), 67-79.

Mautino, L.R., Vergel, M.M. and Anzótegui, L.M. 1998b. Palinología de la Formación Melo (Pérmico Inferior) en Arroyo Seco, Departamento de Rivera, República Oriental del Uruguay. Parte III: Especies nuevas. Revista Española de Micropaleontología, 30 (3), 107-110.

Mautino, L.R., Vergel, M.M. and Anzótegui, L.M. 1998c.
Palinología de la Formación Melo (Pérmico Inferior) en Arroyo Seco, Departamento de Rivera, Uruguay. Parte V: granos de polen, acritarcas e Incertae sedis. Ameghiniana, 35 (3), 299-314.

Milani, E.J., Melo, J.H.G., Souza, P.A., Fernandes, L.A. and França, A.B. 2007. Bacia do Paraná. Boletim de Geociências da Petrobrás, 15 (2), 265-287.

Mori, A.L.O. and Souza, P.A. 2010. Palinologia das formações Rio Bonito e Palermo (Permiano Inferior, Bacia do Paraná) em Candiota, Rio Grande do Sul, Brasil: novos dados e implicações bioestratigráficas. Ameghiniana, 47 (1), 61-78.

Mori, A.L.O. and Souza, P.A. 2012. Análise palinoestratigráfica dos depósitos permianos (poços HN-05-RS e HN-25-RS) do sul da Bacia do Paraná. Ameghiniana, 49 (3), 319-342.

Neregato, R., Souza, P.A. and Rohn, R. 2008. Registros palinológicos inéditos nas formações Teresina e Rio do Rasto (Permiano, Grupo Passa Dois, Bacia do Paraná): Implicações biocronoestratigráficas e paleoambientais. Pesquisas em Geociências, 35 (2), 9-21.

Picarelli, A., Dias-Fabricio, M. E. e Cazzulo - Klepzig, M. 1987. Considerações sobre a paleoecologia e a palinologia da jazida carbonífera de Santa Terezhina, RS, Brasil Permiano da Bacia do Paraná. III Simpósio sul - brasileiro de geologia, Curitiba, 351-372.

Playford, G. and Dino, R. 2000a. Palynostratigraphy of upper Palaeozoic strata (Tapajós Group), Amazonas Basin, Brazil: Part one. Palaeontographica Abt. B., 255, 1-46.

Playford, G. and Dino, R. 2000b. Palynostratigraphy of upper Palaeozoic strata (Tapajós Group), Amazonas Basin, Brazil: Part two. Palaeontographica Abt. B., 255, 87-145.

Premator, E., Fischer, T.V. and Souza, P.A. 2006. Palinologia da Formação Iratí (Permiano Inferior da Bacia do Paraná), en Montividiu, Goiás, Brasil. Revista del museo argentino de ciencias naturales, n.s, 8 (2), 221-230.

Schneider, R.L., Muhlmann, H., Tommasi, E., Medeiros, R.A., Daemon, R.A. and Nogueira, A.A. 1974. Revisão estratigráfica da Bacia do Paraná. XXVIII Congresso Brasileiro de Geologia, Porto Alegre, 1, 41-65.

Souza, P.A. 2006. Late Carboniferous palynostratigraphy of the Itararé Subgroup, northeastern Paraná Basin, Brazil. Review of Palaeobotany and Palynology, 138 (1), 9-29.

Souza, P.A. and Marques-Toigo, M. 2003. An overview on the Palynostratigraphy of the Upper Paleozoic strata of the Brazilian Paraná Basin. Revista del Museo Argentino de Ciencias Naturales, n.s., 5 (2), 205-214.

Souza, P.A., Petri, S. and Dino, R. 2003. Late Carboniferous palynology from the Itararé Subgroup (Paraná Basin) at Araçoiaba da Serra, São Paulo State, Brazil. Palynology, 27 (1), 39-74.

Souza, P.A., Saad, A.R. and Lima, M.R. 1997. Palinologia dos carvões paleozoicos do Estado de São Paulo. II - 0 Carvão de Monte Mor. Revista do Instituto Geológico São Paulo, 18 (1/2), 7-21.

Souza, P.A., Félix, C., Perez-Aguilar, A. and Petri, S. 2010a. Pennsylvanian palynofloras from the Itu rhythmites (Itararé Subgroup, Paraná Basin) in São Paulo State, Brazil. Revue de micropaléontologie, 53 (2), 69-83.

Souza, P.A., Matzembacher, L.T., Abelha, M. and Borghi, L. 
2010b. Palinología da Formação Piauí, Pensilvaniano da Bacia do Parnaíba: Biocronoestratigrafia de intervalo selecionado do poço 1-UN-09-PI (Caxias, MA, Brasil). Revista Brasileira de Paleontologia, 13 (1), 57-66.

Tiwari, R.S. 1999a. Paradigm of FAD, LAD and DOD of some miospore taxa in Late Permian and Early Triassic successions on the Indian Peninsula. Journal of the Palaeontological Society of India, 44, 69-89.

Tiwari, R.S. 1999b. Towards a Gondwana palynocronology. Journal of the Palaeontological Society of India, 44, 1-14.
Vaz, P.T., Rezende, N.G.A.M., Wanderley Filho, J. and Travassos, W.A.S. 2007. Bacia do Parnaíba. Boletim de Geociências da Petrobras, 15 (2), 253-263.

Venkatachala, B.S., Tiwari, R.S. and Vijaya. 1995. Diversification of spore-pollen "character states" in the Indian Permian. Review of Palaeobotany and Palynology, 85 (3/4), 319-340.

Ybert, J.P. 1975. Estude des miospores du Bassin Houiller de Candiota - Hulha Negra, Rio Grande do Sul, Bresil. Pesquisas, 5, 181-226.

Recibido: junio 2017

Revisado: diciembre 2017

Aceptado: febrero 2018

Publicado: diciembre 2018 